\title{
HAS the Long-Term ReVERsal REVERSED? EVIDENCE FROM COUNTRY EQUITY INDICES
}

\author{
Adam ZAREMBA*
}

\begin{abstract}
This study reexamines the long-term reversal anomaly across international stock market indices. We investigate a comprehensive and up-to-date sample of 74 countries for the years 1995-2015. By controlling for country-level value, size and momentum effects, we provide convincing evidence that the long-run reversal effect has reversed in the examined period, so that past winners outperform losers. The outcomes are robust to impact of country-specific tax rates on dividends, different portfolio weighting schemes or alternative sorting periods. The "reverse reversal anomaly" is strongest for large markets, nonetheless it is observable in a broad range of subsets, independently of market liquidity, level of development, country financial openness, pricing or short term past performance.
\end{abstract}

Keywords: long-term reversal, stock market indices, country stock markets, countrylevel anomalies, international markets, asset pricing, investment strategies

JEL Classification: G11, G12, G15

\section{Introduction}

The long-run reversal effect is a tendency of companies with poor past long-term ( 3 to 5 years) performance (loser companies) to outperform firms with good past long-term ( 3 to 5 years) performance (winner companies). The initial evidence on this anomaly was provided by de Bondt and Thaler (1985), who show that for portfolios of US stocks sorted on past 3 to 5 -year returns, losers have high future returns whereas winners have low future returns. The authors explained their observation on the basis of investor overreaction. Furthermore, Fama and French (1996) document that the long-term reversal anomaly may be actually explained by the value factor from their three-factor asset-pricing model.

Interestingly, the parallel long-run reversal pattern was also found for the stock markets indices. Richards (1997) investigated a sample of 16 national stock markets for years 1969-1995 and found out that the markets with low past 3-5 years returns outperform

*Adam Zaremba, Poznań University of Economics and Business, Department of Investment and Capital Markets, Poznań. E-mail: adam.zaremba@ue.poznan.pl. 
Has the Long-Term Reversal Reversed?

markets with past high returns. These results were later confirmed within broader samples by Balvers et al. (2000), Balvers and Wu (2006), and Smith and Pantilei (2015). Particularly, Spierdijk et al. (2012) found convincing evidence supporting long-run reversal across markets in a sample of 18 OECD countries for years 1900-2009. Finally, Malin and Bornholt (2013) discovered that the long-term reversal across stock market indices has markedly weakened for developed countries after year $1990 .^{1}$

The potential explanations of the long-term underperformance usually refer to investor under- and overreaction. An interpretation of the result is that reversals are the outcome of cross border equity flows being insufficient to remove mispricing, perhaps due to investors' fears of expropriation or capital controls

The aim of this paper is to reexamine the performance of the country-selection strategy based on long-term underperformance. This study aims to contribute in a few ways. First, we attempt to provide fresh and largely out-of-sample evidence by investigating a comprehensive and up-to-date sample of 74 countries for years 1995-2015. Contrary to the previous studies, this research accounts for influence of various weighting schemes and taxes on dividends. Second, by using a country-level cross-sectional four-factor asset-pricing model, we try to control for intermarket value, size and momentum effects. Thirdly, we test and compare, whether the strategy is equally strong in various types of markets and whether it is dependent on their level of development, financial openness, size, liquidity, pricing or short-term past performance.

We find out that the long-run reversal effect across country indexes has actually reversed in the recent 20 years. The past long-term winners significantly outperform losers. The outcomes are robust to impact of tax rates on dividends, which vary across countries, different portfolio weighting schemes and alternative sorting periods. The reverse reversal anomaly is strongest for large markets, nonetheless it is observable in a large number of subsets, independent of market liquidity, level of development, country financial openness, pricing or short term past performance.

The rest of the paper is organized as follows: the next section presents research methods and data sources, which is followed by findings and conclusions.

\section{Methods and Data Sources}

The study aims to test the performance of portfolios formed on long-term past returns. In Section II.3 we present the data sources, procedures used in constructing the portfolios, as well as the asset pricing models and testing methods we employed.

\section{II.1 Playing Field}

This research is based on returns on international stock market indices from 74 countries. ${ }^{2}$ All source data are obtained from the Bloomberg database. Monthly time-

\footnotetext{
${ }^{1}$ A review of relevant studies is provided by Jordan (2012).

2 Argentina, Australia, Austria, Bahrain, Bangladesh, Belgium, Brazil, Bulgaria, Canada, Chile, China, Colombia, Croatia, Cyprus, Czech Republic, Denmark, Egypt, Estonia, Finland, France, Germany, Greece, Hong Kong, Hungary, Iceland, India, Indonesia, Ireland, Israel, Italy, Japan, Jordan, Kazakhstan, Kenya, Kuwait, Lebanon, Lithuania, Malaysia, Mexico, Morocco, Netherlands, New Zealand, Nigeria, Norway, Oman, Pakistan, Peru, Philippines, Poland, Portugal, Qatar, Romania, Russia, Serbia, Saudi Arabia, Singapore, Slovenia, South Africa,
} 
series are implemented as they provide a sufficient number of observations to ensure the effectiveness of the tests and allow avoiding excessive exposure to microstructure issues (de Moor and Sercu, 2013). We adopt the MSCI indices for all the countries to maintain a consistent return computation methodology. The MSCE indices represent capitalization-weighted benchmarks that are commonly tracked worldwide. Additionally, these indices constitute the basis for numerous futures contracts and over 650 exchanged traded funds all over the world. ${ }^{3}$ Therefore, our decision to adopt $\mathrm{MSCl}$ also aims at aligning this research with the investment practice. These indices are constructed and managed with a view to being fully investable from the perspective of international institutional investor ( $\mathrm{MSCl}, 2014 \mathrm{a})$, and cover about $85 \%$ of stock market capitalizations in countries they represent (MSCl, 2014b). In a country where the $\mathrm{MSCl}$ index is unavailable, the Dow Jones was our second index of choice (Cyprus and Iceland). ${ }^{4}$ The detailed data composition is presented in Table A1 in the Appendix.

The returns are computed based on capitalization-weighted gross total return indices, i.e. the returns are adjusted for corporate actions (splits, reverse splits, issuance rights etc.) and cash distributions to investors (dividends). The sample period runs from January 1995 to February 2015, as available. Nonetheless, the first 36-60 month serve only as the basis for country rankings necessary for portfolio formation, so the actual sample period for returns starts in January 1999. Eventually, the number of monthly observations in the time series of the examined returns varied from 182 to 206, dependent on the portfolio formation period. The total sample includes 74 country equity markets. Both existing and discontinued indices (e.g. MSCI Venezuela) are used to avoid a survivorship bias. ${ }^{5} \mathrm{~A}$ stock market is included in the sample in month $t$ if it is possible to compute: its capitalization and book-to-market $(B / M)$ ratio at the end of month $t-1$, return in month $t$ and an appropriate long-term return that constitute a basis for the examined strategy. The precise number of countries in the sample was growing along with the development of the global capital market from 14 in January 1995 to 72 in February 2015, and the time-series average was 49.

The initial index values and capitalizations are collected in local currencies, however, we agree with Liew and Vassalou (2000) and Bali et al. (2013) that comparisons using different currency units could be misleading. This is especially true in the emerging and frontier markets, where inflation and risk-free rates are sometimes very high and differ significantly across markets. Therefore, we follow the approach of Liu et al. (2011), Bekaert et al. (2007), or Brown et al. (2008), and denominate all data in US dollars to obtain polled international results. In order to be consistent with the USD approach, excess returns are computed over returns on a Bloomberg generic US 1-month T-bill.

South Korea, Spain, Sri Lanka, Sweden, Switzerland, Taiwan, Thailand, Trinidad and Tobago, Tunisia, Turkey, Ukraine, United Arab Emirates, United Kingdom, USA, Venezuela, Vietnam.

${ }^{3}$ Data from http://www.msci.com/products/indexes/ [accessed 1 November 2014].

${ }^{4}$ In order to test the robustness of the results, we replicated the study within a sample excluding the non-MSCl indices. This robustness check yielded no qualitative differences in results.

${ }^{5}$ In order to test the robustness of the results, we replicated the study within a sample excluding the non-surviving indices, e.g., MSCI Venezuela. This robustness check yielded no qualitative differences in results. 


\section{II.2 Examined Portfolios and Strategies}

In this paper, we research the performance of portfolios formed on past performance. Thus, at the end of each month $t-1$, all stock market indices are ranked against their long-term returns. For the past long-term performance measurement, we closely follow the approach of Malin and Bornholt (2013). We sort the countries on their cumulative past 60-month excess return with the most recent 12 months excluded (so as to disentangle the influence of momentum effect) ${ }^{6}$ In other words, the indices are ranked on their total excess return in months $t-60$ to $t-13$. Next, we define the 20th, 40th, 60th and 80th percentiles as breakpoints and thus form five subgroups. Finally, the indices in the respective subgroups are capitalization-weighted to form portfolios. ${ }^{7} \mathrm{We}$ subsequently add differential portfolios - effectively synthetic zero-portfolios - that form long/short portfolios: $100 \%$ long in the quintile of markets with the highest metrics, and $100 \%$ short in the quintile of markets with the lowest metrics.

When calculating the returns on portfolios, we first aggregate the single-period arithmetic returns in the cross section so as to form portfolios, and subsequently convert them into log returns for statistical interfering.

\section{II.3 Performance Evaluation}

Examining multi-country international portfolios requires an appropriate asset-pricing model. The model should comply with the perspective of an international investor, motivated to invest in foreign indices-based instruments, e.g. ETFs or futures contracts. Furthermore, it should control for existing intermarket asset pricing effects, which may potentially explain the variation in returns. Therefore, we employ a country-level fourfactor model. The model was originally developed by Carhart (1997) and, subsequently, employed for the country level data by Zaremba (2015). It described with the following regression: 8

$\mathrm{R}_{\mathrm{i}, \mathrm{t}}=\alpha_{\mathrm{i}}+\mathrm{R}_{\mathrm{f}, \mathrm{t}}+\beta_{\mathrm{rm}, \mathrm{i}} \cdot\left(\mathrm{R}_{\mathrm{m}, \mathrm{t}}-\mathrm{R}_{\mathrm{f}, \mathrm{t}}\right)+\beta_{\mathrm{SMB}, \mathrm{i}} \cdot \mathrm{SMB}_{\mathrm{t}}+\beta_{\mathrm{HML}, \mathrm{i}} \cdot \mathrm{HML}_{\mathrm{t}}+\beta_{\mathrm{WML}, \mathrm{i}} \cdot \mathrm{WML}_{\mathrm{t}}+\varepsilon_{\mathrm{i}, \mathrm{t}}$

where: $\beta_{r m, i}, \beta_{S M B, i}, \beta_{H M L, i}, \beta_{W M L, i}$, and $\alpha_{i}$ are the model estimated parameters; $\beta_{r m, i}$ is analogous, but not equal, to CAPM beta. $\beta_{S M B, i}, \beta_{H M L, i}, \beta_{W M L, i}$, are measures of exposure to $S M B_{t}$ (small minus big), $H M L_{t}$ (high minus low), and $W M L_{t}$ (winners minus losers) risk factors, which are defined as the returns on the zero-cost arbitrage portfolios. $S M B_{t}$ is the difference in returns on diversified portfolios between small and large markets at time $t$ while $H M L_{t}$ is, in general, the difference between returns on

${ }^{6}$ For more detailed information on momentum effect see, for example, Fama and French (2012), Bali et al. (2013), Asness et al. (2013) or Zaremba and Konieczka (2015b). The momentum across international stock market indices was documented among others by Balvers and Wu (2006) and Bhojraj and Swaminathan (2006).

7 It is common in country level studies to equal-weight the indices in portfolios, as it is assumed to be easily achieved with for instance liquid futures (see for example Asness et al., 2013). Nonetheless, we deem this approach may, however, distort the results in at least two ways. First, by assuming monthly inflows and outflows from markets that may be characterised by constrained size, liquidity and capacity; second, by being influenced by the so called diversification return (Willenbrock, 2011).

8 The model was initially proposed in a paper by Zaremba (2014). We closely follow this approach. 
portfolios of diversified value (high book-to-market) and growth (low book-to-market) markets. Finally, $W M L_{t}$ covers momentum returns measured by returns on the so-called winner and loser portfolios, which were used in the initial studies on this anomaly (Jegadeesh and Titman, 1993). The WML,t (winners minus losers) denotes the difference between returns on the diversified winner and loser portfolios in the preceding year. In other words, $S M B_{t}, H M L_{t}$, and $W M L_{t}$ are returns on zero-cost market-neutral long or short portfolios formed based on size, value, and momentum characteristics. The precise description of the model is provided in Zaremba (2015).

The model is identical as the four-factor model introduced by Carhart (1997), but all the asset-pricing factors are estimated based on returns on $\mathrm{MSCl}$ stock market indices. In other words, we effectively test whether the long-term performance-based equity market selection strategies expand the frontier of an international index investor with an exposition to country-level market, value, size and momentum anomalies. ${ }^{9}$

The market risk is calculated as an excess return over the risk-free rate of a capitalization-weighted portfolio formed from all country indices in the sample. In order to compute the three remaining classical cross-sectional factors (HML, SMB and $W M L)$, the indices at time $t-1$ are sorted on their $\mathrm{B} / \mathrm{M}$ ratio ${ }^{10}$, size (a total stock market capitalization) and momentum (lagged cumulative return from time $t-12$ to $t-1$ ). The explanatory factor returns were formed from $2 \times 3$ sorts on size and B/M or size and momentum. Big markets and small markets are defined as those with the capitalization above and below the median at $t-1$. The B/M breakpoints in the $2 \times 3$ sorts are the $30^{\text {th }}$ and $70^{\text {th }}$ percentiles of $B / M$ for the all the indices at $t-111$. The intersection of the independent $2 \times 3$ sorts on size and B/M produces six portfolios - SG, SN, SV, BG, BN, and $B V$, where $S$ and $B$ indicate small or big and $G, N$, and $V$ indicate growth, neutral, and value (bottom $30 \%$, middle $40 \%$, and top $30 \%$ of B/M), respectively. The next phase is to compute monthly capitalization-weighted returns for all six portfolios. Finally, the $t$ month return on the size factor, $S M B$, is calculated as the equal-weighted average of returns on the three small country portfolios from the $2 \times 3$ size-B/M sorts minus the average of returns on the three big country portfolios. The return on value factor, $H M L$, is the difference between equal-weighted returns on value portfolios $(B V, S V)$ and the equal-weighted average of the returns on growth portfolios (BG, SG). The $2 \times 3$ sorts on size and momentum are performed in the same way as the size-B/M sorts, but with the lagged momentum return replacing $\mathrm{B} / \mathrm{M}$. For portfolios created at the end of month $t-1$, the lagged momentum return is the stock's cumulative return for the months $t-12$ to $t-2$. We follow Fama and French (2012) and skip the sort month, which is the standard way of avoiding short-term reversal in momentum tests. The momentum breakpoints are used to build a two by three matrix, identical to that for $H M L$. The WML return in month $t$ is computed as the difference between the equal-weighted average of the returns on

\footnotetext{
9 These three effects were so far documented across country equity indices: size by Keppler and Traub (1993) and Keppler and Encinosa (2011), value by Macedo (1995) and Kim (2012), and momentum by Balvers and Wu (2006) and Bhojraj and Swaminathan (2006).

10 The $\mathrm{B} / \mathrm{M}$ ratio is always lagged four months in order to avoid a look-ahead bias.

${ }^{11}$ So as to compute the index-level B/M ratio, we first aggregate book values of all the companies, by weighting them according to a particular index methodology, and then divide the sum by the total stock market capitalization of all companies in the given index.
} 
small and large winner indices ( $S W, B W$ ) and the equal-weighted average of returns on small and big loser indices (SL, BL).

Following Fama and French (2012), all the regression parameters are estimated using the OLS regressions, in line with remarks of Cochrane (2005), who regards this method as usually more robust than for example GLS. Furthermore, $t$-statistics corresponding to the parameters are estimated using bootstrap standard errors, so as not to take any distributional assumption. ${ }^{12}$ The test's null hypothesis is that an intercept from the model is equal to 0 , with the alternative hypothesis that it is not.

Furthermore, so as to examine whether the excess returns (intercepts) are systematically increasing along with the deterioration of long-run past performance, we also carry out a monotonic relation (MR) test introduced by Patton and Timmermann (2010). This is a simulation-based test, where the basic hypothesis is that there is no monotonic pattern in excess returns or intercepts (their values do not increase along with the weakening past long-term performance), with an alternative hypothesis, that such pattern exists. The precise testing procedure is described in a paper by Patton and Timmerman (2010). Each MR test in this paper is based on 10.000 random draws, and applied to both raw excess returns and intercepts from the four-factor model.

\section{II.4 Robustness Checks}

We perform a battery of robustness checks. First, we examine two alternative weighting schemes. On the one hand, we employ popular equal-weighting, used for example by Asness et al. (2013). On the other hand, we adopt also liquidity-weighting. In the case of the latter, we apply 12-month average turnover as a proxy for stock market liquidity. Second, we control for the impact of taxes on dividends. To this end, we use MSCI Net Total Return Indices. Contrary to "gross" indices, they account for tax rates on dividends, which vary from country to country. In this approach, the asset pricing factors, that are inputs to the four factor model, are also calculated in the "net" regime. Our motivation for this robustness test is that the taxes could be potentially important for some value-related anomalies. For instance, Zaremba and Konieczka (2015a) find out that the country-level linkage between dividend yields and expected returns disappears after controlling for differences in tax rates. Furthermore, the link between stock-level value strategies and past long-term returns is confirmed by both theoretical (Daniel et al., 1998) and empirical (Fama \& French, 1996) evidence.

Third, we use alternative sorting periods. Following Malin and Bornholt (2013), we sort equity indices also on past 36-month and 48-month performance. Nevertheless, in both cases the most recent 12 months are excluded.

Fourth, we form an array of double sorted portfolios and test their performance in the same manner as the single sorted portfolios. To this end, we initially sort markets on additional variables, divide the sample by a median of a given variable, and then test the strategies within the specific subsets of the entire sample. We use a range of additional sorting variables. First, some anomalies may be heavily influenced by size, so we test the strategies separately in large and small markets. ${ }^{13}$ Second, the

12 The bootstrap standard errors were calculated based on 10.000 random draws.

${ }^{13}$ For example Hong et al. (2000) and Zhang (2006) find out that momentum effect is stronger across small firms. 
profitability of some anomalies strongly depends on market liquidity, so we also divide markets by their average turnover during past 12 months. ${ }^{14}$ Third, following the approach of Zaremba and Konieczka (2015a), we examine the country-selection techniques exclusively in the open $(\mathrm{O})$ and close $(\mathrm{C})$ markets. To this end, for each month we sort countries based on their KAOPEN indices (Chin and Ito, 2008) measuring the country's de jure degree of capital account openness and applied as a rough proxy for investment accessibility - and define open economies as having the index above median and close economies with the index below median. Fourth, we examine the linkages with value and momentum effects (Asness et al., 2013). In order to accomplish this target, we sort markets on their B/M ratios (lagged 4 months) to obtain value and growth markets, and on their excess returns performance in months $t-12-t$ 2 to obtain up and down markets. Finally, following Malin and Bornhold (2013), we test the performance of portfolios from sorts on past long-run returns separately in developed and emerging markets. However, contrary to these researchers, we do not use any constant time-invariant arbitrary division, but we dynamically follow $\mathrm{MSCl}$ Market Classification Framework with all the classification changes that took place over time. ${ }^{15}$ The subset of developed markets in a given month contains the developed markets according to the $\mathrm{MSCl}$ classification, while the "emerging" category encompasses all the remaining markets: emerging, frontier or standalone.

\section{Research Results}

Table 1 presents the performance of portfolios from sorts on 60-month past performance. The outcomes of our analysis vividly contradict the initial evidence provided by Richards (1997).

The raw returns and the intercepts from the four-factor model decrease systematically along with the deterioration of past returns and the MR test definitely detects no increasing monotonic pattern. Although the past winners are slightly more risky in terms of both standard deviation and extreme negative returns (worst month $-49.5 \%$ ), they still have higher Sharpe ratios than loser portfolios. The mean excess return on "Iosers minus winners" portfolio is equal to $-1.22 \%$ and it is significantly different from 0 . The negative abnormal returns are also not explained by cross-country value, size and momentum effects. The intercept from the country-level four-factor asset-pricing model is equal $-1.09 \%$ and significantly differs from 0 .

Table 2 reports the performance of portfolios formed on long-run past returns with alternative sorting periods: 36 and 48 months. The inverted reversal effect is much weaker in this approach, but nonetheless we detect no long-run reversal in its traditional understanding. There is no monotonic relation detected by the MR test, and the alphas and returns on sorted portfolios are uneven and do not present any clear pattern. The same observation refers to Sharpe ratios. The returns on the long/short portfolios are negative, but do not differ significantly from 0 after controlling for value, size and momentum effects.

\footnotetext{
${ }^{14}$ See for example Avramov et al. (2015).

15 See http://www.msci.com/products/indexes/market_classification.html [accessed 14 March 2015].
} 
Has the Long-Term Reversal Reversed?

Table 1

Excess Returns on Portfolios from Sorts on Long-term Past Returns

\begin{tabular}{lccccccc}
\hline & $\mathrm{W}$ & 2 & 3 & 4 & $\mathrm{~L}$ & $\mathrm{~L}-\mathrm{W}$ & $\mathrm{MR}$ \\
\hline Mean & $0.93^{\star}$ & 0.66 & 0.66 & 0.23 & 0.13 & $\mathbf{- 1 . 2 2}$ & 48.4 \\
& $(1.67)$ & $(1.56)$ & $(1.21)$ & $(0.59)$ & $(0.25)$ & $\mathbf{( - 2 . 3 6 )}$ & \\
Stand. deviation & 8.26 & 6.67 & 7.08 & 6.33 & 6.31 & 7.37 & \\
Sharpe ratio & 0.39 & 0.34 & 0.32 & 0.13 & 0.07 & -0.57 & \\
Worst month & -49.60 & -30.31 & -36.97 & -24.69 & -24.25 & -23.10 & \\
Best month & 26.29 & 17.78 & 23.18 & 16.98 & 18.55 & 21.51 & \\
Skewness & -1.15 & -0.63 & -0.73 & -0.28 & -0.57 & -0.16 & \\
Kurtosis & 6.88 & 1.87 & 4.24 & 0.96 & 1.61 & 0.95 & \\
Observations & 193 & 193 & 193 & 193 & 193 & 193 & \\
Intercept & 0.24 & 0.10 & -0.03 & -0.46 & -0.42 & $\mathbf{- 1 . 0 9}$ & 35.8 \\
& $(0.97)$ & $(0.38)$ & $(0.03)$ & $(-1.62)$ & $(-1.42)$ & $\mathbf{( - 2 . 4 2 )}$ & \\
\hline
\end{tabular}

Source: Own elaborations based on data from the Bloomberg database.

Notes. The table reports basic statistics of excess returns on capitalization-weighted quintile portfolios from sorts on their past 60-month formation period with the 12 most recent months excluded. The loser portfolio "L" contains the $20 \%$ of stock markets with the lowest returns, and the winner portfolio "W" contains the $20 \%$ of stock markets with the highest returns. "L-W" is the long/short portfolio that longs the loser portfolio and shorts the winner portfolio. Intercepts are intercepts from the four-factor countrylevel model. "MR" is a p-value corresponding to the test of Monotonic Relation by Patton and Timmerman (2010). Excess returns, standard deviations, best and worst months, intercepts, and pvalues are expressed in percentage. The numbers in brackets are $t$-statistics and the significance at $5 \%$ level is in bold characters. * and ${ }^{* *}$ indicate values significantly different from 0 at $10 \%$ and $5 \%$ level respectively.

Table 2

\section{Performance of Portfolios from Sorts on Long-term Past Returns: Alternative Sorting Periods}

\begin{tabular}{lccccccc}
\hline & $\mathrm{H}$ & 2 & \multicolumn{7}{c}{3} & 4 & $\mathrm{~L}$ & $\mathrm{~L}-\mathrm{H}$ & $\mathrm{MR}$ \\
\hline \multirow{7}{*}{ Mean } & 0.69 & 0.24 & 0.27 & 0.41 & 0.53 & -0.29 & 51.3 \\
& $(1.30)$ & $(0.51)$ & $(0.70)$ & $(0.92)$ & $(1.08)$ & $(-0.44)$ & \\
Standard deviation & 8.71 & 6.65 & 6.30 & 6.63 & 6.78 & 7.69 & \\
Sharpe ratio & 0.27 & 0.12 & 0.15 & 0.21 & 0.42 & -0.13 & \\
Intercept & 0.17 & -0.44 & -0.33 & -0.05 & 0.41 & -0.19 & 62.4 \\
& $(0.58)$ & $(-1.65)$ & $(-1.15)$ & $(-0.17)$ & $(1.29)$ & $(-0.42)$ & \\
\hline \multirow{7}{*}{ Sorting period: 48 months } & & & \\
Mean & 0.70 & 0.47 & 1.02 & 0.24 & 0.33 & $-0.77^{*}$ & 83.6 \\
Standard deviation & $(1.36)$ & $(1.08)$ & $(2.37)$ & $(0.64)$ & $(0.74)$ & $(-1.69)$ & \\
Sharpe ratio & 8.10 & 6.90 & 6.59 & 6.90 & 6.03 & 7.08 & \\
Intercept & 0.30 & 0.24 & 0.53 & 0.12 & 0.19 & -0.37 & \\
& -0.01 & -0.12 & 0.38 & -0.41 & -0.09 & -0.49 & 70.9 \\
\hline Source: Oran & $(0.04)$ & $(-0.36)$ & $(1.31)$ & $(-1.26)$ & $(-0.35)$ & $(-1.16)$ & \\
\hline
\end{tabular}

Source: Own elaborations based on data from the Bloomberg database.

Notes. The table reports basic statistics of excess returns on capitalization-weighted quintile portfolios from sorts on their past J-month formation period returns for $J=36$ and 48 months with the 12 most recent months excluded. The loser portfolio "L" contains the $20 \%$ of stock markets with the lowest returns, and the winner portfolio "W" contains the $20 \%$ of stock markets with the highest returns. " $L-W$ " 
is the long/short portfolio that longs the loser portfolio and shorts the winner portfolio. Intercepts are intercepts from the four-factor country-level model. "MR" is a p-value corresponding to the test of Monotonic Relation by Patton and Timmerman (2010). Excess returns, standard deviations, intercepts and $p$-values are expressed in percentage. The numbers in brackets are t-statistics and the significance at $5 \%$ level is in bold characters. * and ${ }^{* *}$ indicate values significantly different from 0 at $10 \%$ and $5 \%$ level, respectively.

The outcomes of alternative weighting methods depicted in Table 3 confirm that the reverse reversal effect is not a kind of a data mining exercise. Additionally, it withstands the impact of taxes of dividends that vary from country to country. In all the variants presented in Table 3, the return pattern is decreasing, not increasing. In other words, the lower past long-term returns are accompanied by lower future returns. No MR test confirms the opposite pattern. The influence of taxes on dividends does not play an important role, as the results of the analysis are similar in both approaches. The excess return and abnormal returns are negative and in most cases significantly differ from 0. The inverted reversal effect is strongest for capitalization- and liquidity weightedportfolios, and somewhat weaker in equally weighted portfolios. It may suggest that the reversal effect is strongest across the large and liquid markets and weaker across the small markets.

Table 3

Performance of Portfolios from Sorts on Long-term Past Returns: Alternative Weighting Schemes and Impact of Taxes on Dividends

\begin{tabular}{|c|c|c|c|c|c|c|c|}
\hline & $\mathrm{H}$ & 2 & 3 & 4 & $\mathrm{~L}$ & $\mathrm{~L}-\mathrm{H}$ & MR \\
\hline \multicolumn{8}{|c|}{ Capitalization-weighted portfolios: net returns } \\
\hline \multirow[t]{2}{*}{ Mean } & 0.85 & 0.53 & 0.53 & 0.13 & 0.10 & $-1.18^{\star \star}$ & 43.6 \\
\hline & $(1.50)$ & $(1.27)$ & $(0.95)$ & $(0.35)$ & $(0.19)$ & $(-2.28)$ & \\
\hline \multirow[t]{2}{*}{ Intercept } & 0.18 & -0.01 & -0.14 & $-0.54^{*}$ & -0.43 & $-1.06^{\star \star}$ & 31.3 \\
\hline & $(0.70)$ & $(0.02)$ & $(-0.35)$ & $(-1.91)$ & $(-1.46)$ & $(-2.33)$ & \\
\hline \multicolumn{8}{|c|}{ Equal-weighted portfolios: gross returns } \\
\hline \multirow[t]{2}{*}{ Mean } & 0.64 & 0.52 & 0.54 & 0.43 & 0.40 & $-0.37^{*}$ & 28.6 \\
\hline & (1.43) & (1.38) & $(1.32)$ & $(1.14)$ & $(0.90)$ & $(-1.74)$ & \\
\hline \multirow[t]{2}{*}{ Intercept } & 0.01 & -0.02 & -0.06 & -0.17 & -0.23 & -0.37 & 19.5 \\
\hline & $(0.00)$ & $(0.14)$ & $(-0.04)$ & $(-0.18)$ & $(-0.87)$ & $(-1.16)$ & \\
\hline \multicolumn{8}{|c|}{ Equal-weighted portfolios: net returns } \\
\hline \multirow[t]{2}{*}{ Mean } & 0.59 & 0.47 & 0.39 & 0.36 & 0.37 & $-0.34^{*}$ & 26.2 \\
\hline & $(1.30)$ & $(1.22)$ & $(0.97)$ & $(0.98)$ & $(0.85)$ & $(-1.68)$ & \\
\hline \multirow[t]{2}{*}{ Intercept } & -0.05 & -0.08 & -0.2 & -0.22 & -0.24 & -0.33 & 19.8 \\
\hline & $(-0.14)$ & $(-0.36)$ & $(-0.74)$ & $(-1.14)$ & $(-1.22)$ & $(-1.34)$ & \\
\hline \multicolumn{8}{|c|}{ Liquidity-weighted portfolios: gross returns } \\
\hline \multirow[t]{2}{*}{ Mean } & 0.71 & 0.41 & 0.36 & 0.10 & 0.12 & $-0.75^{\star \star}$ & 64.8 \\
\hline & (1.43) & $(1.03)$ & $(0.90)$ & $(0.31)$ & $(0.18)$ & $(-2.41)$ & \\
\hline \multirow[t]{2}{*}{ Intercept } & 0.07 & -0.19 & -0.21 & $-0.47^{* *}$ & $-0.53^{*}$ & $-0.75^{\star \star}$ & 47.0 \\
\hline & $(0.25)$ & $(-0.80)$ & $(-0.92)$ & $(-2.07)$ & $(-1.83)$ & $(-2.19)$ & \\
\hline \multicolumn{8}{|c|}{ Liquidity-weighted portfolios: net returns } \\
\hline \multirow[t]{2}{*}{ Mean } & 0.64 & 0.36 & 0.24 & -0.02 & 0.03 & $-0.76^{\star *}$ & 52.9 \\
\hline & (1.29) & $(0.87)$ & $(0.59)$ & $(0.00)$ & $(-0.06)$ & $(-2.52)$ & \\
\hline \multirow[t]{2}{*}{ Intercept } & -0.01 & -0.24 & -0.35 & $-0.57^{\star \star}$ & $-0.58^{\star \star}$ & $-0.73^{\star \star}$ & 33.2 \\
\hline & $(-0.03)$ & $(-0.98)$ & $(-1.35)$ & $(-2.59)$ & $(-1.97)$ & $(-2.13)$ & \\
\hline
\end{tabular}


Has the Long-Term Reversal Reversed?

Source: Own elaborations based on data from Bloomberg database.

Notes. The table reports means excess returns and intercepts of capitalization-, equal- and liquidity-weighted quintile portfolios from sorts on their past 60-month formation period with the 12 most recent months excluded. The loser portfolio " $L$ " contains the $20 \%$ of stock markets with the lowest returns, and the winner portfolio "W" contains the $20 \%$ of stock markets with the highest returns. " $\mathrm{L}-W$ " is the long/short portfolio that longs the loser portfolio and shorts the winner portfolio. Intercepts are intercepts from the country-level four-factor model that is described in the section II.3. "MR" is a p-value corresponding to the test of Monotonic Relation by Patton and Timmerman (2010). Excess returns, intercepts and p-values are expressed in percentage. The numbers in brackets are $t$-statistics and the significance at $10 \%$ level is in bold characters. * and ** indicate values significantly different from 0 at 10\% and 5\% level, respectively.

The initial intuition about the relation between market capitalizations and the magnitude of the reversal anomaly are confirmed in Table 4 . The reverse long-run reversal is particularly strong for the large markets. In both gross and net approaches, the negative abnormal returns are significant and surpass $-1.70 \%$. On the other hand, the subset of small markets reveals no significant relation between long-term past and short-term future returns. The excess returns and alphas from the four-factor model on the long/short small market portfolio are very close to 0 . This observation interestingly corresponds with initial findings of Richards (1997), who documented that the reversal effect (in traditional sense) is actually stronger for small markets.

Table 4

Performance of Portfolios Formed on Long-term Past Returns Sorted Initially on Additional Variables

\begin{tabular}{|c|c|c|c|c|c|c|c|c|}
\hline \multirow[b]{2}{*}{ Large } & \multirow{2}{*}{$\begin{array}{c}\text { Mean } \\
-1.93^{\star \star} \\
(-3.62)\end{array}$} & \multicolumn{3}{|c|}{$\begin{array}{l}\text { Raw MR Intercept Intercept MR } \\
\text { Gross returns }\end{array}$} & \multirow{2}{*}{$\begin{array}{c}\text { Mean } \\
-1.95^{\star \star} \\
(-3.64)\end{array}$} & \multicolumn{2}{|c|}{$\begin{array}{r}\text { Raw MR Intercept } \\
\text { Net returns }\end{array}$} & Intercept MR \\
\hline & & 90.5 & $\begin{array}{l}-1.71^{\star *} \\
(-4.06)\end{array}$ & 76.9 & & 94.1 & $\begin{array}{l}-1.72^{\star \star} \\
(-4.07)\end{array}$ & 80.6 \\
\hline Small & $\begin{array}{c}0.01 \\
(0.00)\end{array}$ & 9.6 & $\begin{array}{c}0.00 \\
(-0.03)\end{array}$ & 11.6 & $\begin{array}{l}0.08 \\
(0.16)\end{array}$ & 0.1 & $\begin{array}{l}0.08 \\
(0.20)\end{array}$ & 12.6 \\
\hline Liquid & $\begin{array}{l}-0.98^{* *} \\
(-2.09)\end{array}$ & 87.0 & $\begin{array}{l}-0.77^{*} \\
(-1.75)\end{array}$ & 61.0 & $\begin{array}{l}-0.92^{*} \\
(-1.91)\end{array}$ & 62.6 & $\begin{array}{l}-0.70 \\
(-1.58)\end{array}$ & 32.4 \\
\hline Illiquid & $\begin{array}{l}-0.81 \\
(-1.51)\end{array}$ & 73.2 & $\begin{array}{l}-0.81 \\
(-1.54)\end{array}$ & 78.2 & $\begin{array}{l}-0.73 \\
(-1.42)\end{array}$ & 52.4 & $\begin{array}{l}-0.68 \\
(-1.41)\end{array}$ & 68.0 \\
\hline Developed & $\begin{array}{l}-0.47 \\
(-1.58)\end{array}$ & 11.7 & $\begin{array}{l}-0.55 \\
(-1.63)\end{array}$ & 30.3 & $\begin{array}{l}-0.47 \\
(-1.58)\end{array}$ & 11.7 & $\begin{array}{l}-0.54 \\
(-1.61)\end{array}$ & 29.8 \\
\hline Emerging & $\begin{array}{l}-0.97^{\star *} \\
(-1.97)\end{array}$ & 28.6 & $\begin{array}{l}-0.78 \\
(-1.28)\end{array}$ & 50.4 & $\begin{array}{l}-0.97^{\star *} \\
(-1.97)\end{array}$ & 28.6 & $\begin{array}{c}-0.8 \\
(-1.29)\end{array}$ & 49.1 \\
\hline Open & $\begin{array}{l}-0.85^{\star *} \\
(-2.00)\end{array}$ & 70.6 & $\begin{array}{l}-0.83^{*} \\
(-1.88)\end{array}$ & 49.5 & $\begin{array}{l}-0.90^{* *} \\
(-2.07)\end{array}$ & 51.3 & $\begin{array}{l}-0.85^{\star *} \\
(-1.97)\end{array}$ & 33.4 \\
\hline Closed & $\begin{array}{l}-0.76^{*} \\
(-1.84)\end{array}$ & 48.9 & $\begin{array}{l}-0.74 \\
(-1.53)\end{array}$ & 42.8 & $\begin{array}{l}-0.73^{*} \\
(-1.80)\end{array}$ & 59.9 & $\begin{array}{l}-0.59 \\
(-1.42)\end{array}$ & 39.2 \\
\hline Value & $\begin{array}{l}-0.65 \\
(-1.53)\end{array}$ & 59.3 & $\begin{array}{l}-0.63 \\
(-1.38)\end{array}$ & 52.4 & $\begin{array}{l}-0.67 \\
(-1.57)\end{array}$ & 78.6 & $\begin{array}{l}-0.66 \\
(-1.40)\end{array}$ & 70.0 \\
\hline Growth & $\begin{array}{l}-0.74^{*} \\
(-1.67)\end{array}$ & 99.8 & $\begin{array}{l}-0.65 \\
(-1.38)\end{array}$ & 96.8 & $\begin{array}{l}-0.72 \\
(-1.59)\end{array}$ & 98.6 & $\begin{array}{c}-0.51 \\
(-1.29)\end{array}$ & 92.1 \\
\hline Up & $\begin{array}{l}-0.47 \\
(-1.27)\end{array}$ & 86.4 & $\begin{array}{c}-0.45 \\
(-1.14)\end{array}$ & 74.9 & $\begin{array}{l}-0.37 \\
(-1.03)\end{array}$ & 75.3 & $\begin{array}{c}-0.36 \\
(-0.92)\end{array}$ & 63.0 \\
\hline
\end{tabular}

Romanian Journal of Economic Forecasting - XIX (1) 2016 


\begin{tabular}{|c|c|c|c|c|c|c|c|}
\hline \multirow[b]{2}{*}{ Down } & \multicolumn{3}{|c|}{$\begin{array}{c}\text { Mean Raw MR Intercept Intercept MR } \\
\text { Gross returns }\end{array}$} & \multicolumn{4}{|c|}{$\begin{array}{c}\text { Mean Raw MR Intercept Intercept MR } \\
\text { Net returns }\end{array}$} \\
\hline & $\begin{array}{l}-0.91^{*} \\
(-1.92)\end{array}$ & $\begin{array}{ll}35.6 & -0.88^{*} \\
& (-1.81)\end{array}$ & 33.1 & $\begin{array}{l}-0.89^{*} \\
(-1.93)\end{array}$ & 40.1 & $\begin{array}{l}-0.80^{\star} \\
(-1.79)\end{array}$ & 19.8 \\
\hline
\end{tabular}

Source: Own elaborations based on data from Bloomberg database.

Notes. The table reports means excess returns and intercepts of long/short portfolios from sorts on their past 60- month formation period with the 12 most recent months excluded. "L-W" is the long/short portfolio, that long the loser portfolio and shorts the winner portfolio. The loser portfolio contains the $20 \%$ of stock markets with the lowest returns, and the winner portfolio contains the $20 \%$ of stock markets with the highest returns. The stock indices are initially sorted on their total capitalization (large/small), liquidity (liquid/illiquid), development (developed/emerging), financial openness (open/closed), B/M ratio (value/growth) and momentum (up/down). Intercepts are intercepts from the country-level four-factor model that is described in the section II.3. "MR" is a p-value corresponding to the test of Monotonic Relation by Patton and Timmerman (2010). Excess returns, intercepts and pvalues are expressed in \%. The numbers in brackets are $t$-statistics and the significance at $5 \%$ level is in bold characters. * and ** indicate values significantly different from 0 at $10 \%$ and $5 \%$ level, respectively.

The results presented in Table 4 strongly confirm the robustness of reverse long-term reversal anomaly. In none of the cases the cases (with the exception of small markets), the intercepts or excess returns on portfolios longing the loser markets and shorting the loser markets are positive, neither the MR tests detect any monotonic relation. In fact, the excess returns and intercepts are lower than 0 for all types of additional sorts and the negative abnormal returns are significant for open economies and markets that recently underperformed.

\section{Concluding Remarks}

The study documents that a traditional negative relation between past long-run performance and expected returns has dramatically changed in recent decades. During the last 20 years, the long-run reversal effect across indices turned out to be rather a long-run continuation effect. The top performing countries continue to outperform and the losers continue to lag. These findings are robust to influence of value, size and momentum effects, as well as to various weighting schemes and to the impact of taxes on dividends. The anomaly is present across different subsets of stock markets. These findings may provide valuable lessons for country-level investors, asset managers and fund pickers.

Why has the long-run reversal effect changed? The answer to this question is largely unknown. A number of potential explanations may be offered. First, if the long-run reversal is a form of inefficiency, which it could be obliterated as the global markets became more efficient. In fact, in recent years the international investments become more easily accessible, that should support market efficiency. The prices in global markets are now to greater extend settled globally than locally and cross border equity flows could have became sufficiently large to remove mispricing. Furthermore, Dimson and Marsh (1999) documented that once an apparent anomaly is publicized, it often disappears or goes into reverse. Second, possibly the long-term reversal is not a true anomaly but only a temporary price pattern. Some anomalies that initially seemed to be very promising, were eventually not confirmed in large datasets (see for example Jacobs, 2015). Unfortunately, none of the above hypotheses explains why the long-term 
Has the Long-Term Reversal Reversed?

winners significantly outperform the long-term losers. Finally, it may turn out that our sample is some way specific and thus produces biased results. Indeed, the research period encompass for example the global financial crisis and the period or unprecedentedly low global interest rates, which could potentially influence the results in some way and constitute an essential limitation of this study.

Further research on the issues addressed in this paper might be pursued in a number of directions. First, the interactions between reverse long-run reversal effect and other strategies might be investigated. Second, the potential explanation of the long-run reverse reversal with proxies for limits to arbitrage or market sentiment (see Jacobs, 2015) may warrant further investigation. Third, the impact of transaction costs on the profitability might be explored. Finally, and probably the most importantly, the reasons underlying the observed anomaly require in-depth research.

\section{Acknowledgements}

This study is a part of project no. 2014/15/D/HS4/01235 financed by the National Science Centre of Poland.

\section{References}

Asness, C.S., Moskowitz, T.J. \& Pedersen, L.H., 2013. Value and momentum everywhere. Journal of Finance, 68(3), pp. 929-985.

Avramov, D., Cheng, S., Hameed, A., 2015. Time-varying liquidity and momentum profits. Available at SSRN: http://ssrn.com/abstract=2289745 or http://dx.doi.org/10.2139/ssrn.2289745 [accessed 14 March 2015].

Bali, C., Cakici, N. \& Fabozzi, F., 2013. Book-to-market and the cross-section of expected stock returns in international stock markets. Journal of Portfolio Management, 39(2), pp. 101-115.

Balvers, R., Wu, Y., Gilliland, E., 2000. Mean reversion across national stock markets and parametric contrarian investment strategies. Journal of Finance, 55, pp. 745-772.

Balvers, R.J. \& Wu, Y., 2006. Momentum and mean reversion across national equity indices. Journal of Empirical Finance, 13, pp. 24-48.

Bekaert, G., Harvey, C. \& Lundblad, C., 2007. Liquidity and expected returns: Lessons from emerging markets. Review of Financial Studies, 20(6), pp. 17831831.

Bhojraj, S. \& Swaminathan, B. 2006. Macromomentum: returns predictability in international equity indices. Journal of Business, 79(1), pp. 429-451.

Brown, A., Du, D.Y., Rhee, S.G., \& Zhang, L., 2008. The returns to value and momentum in Asian markets. Emerging Markets Review, 9(2), pp. 7988.

Cochrane J.H., 2005. Asset pricing. Princeton: Princeton University Press.

Carhart, M.M. 1997. On persistence in mutual fund performance. Journal of Finance, 52(1), pp. 57-82. 
Chinn, M.D. \& Ito, H., 2008. A new measure of financial openness. Journal of Comparative Policy Analysis, 10, pp. 309- 322.

Daniel, K., Hirshleifer, D. \& Subrahmanyam, A., 1998. A theory of overconfidence, selfattribution, and security market under and over-reactions. Journal of Finance, 53, pp. 1839-1885.

de Bondt, W.F.M. \& Thaler, R., 1985. Do the stock market overreact? Journal of Finance, 40(3), pp. 793-805.

de Moor, L. \& Sercu, P., 2013. The smallest firm effect: international study. Journal of International Money and Finance, 32, pp. 129-155.

Dimson, E. \& Marsh, P., 1999. Murphy's law and market anomalies. Journal of Portfolio Management, 25(2), pp. 53-69.

Fama, E.F. \& French, K.R., 1996. Multifactor explanations of asset pricing anomalies. Journal of Finance, 51(1), pp. 55-84.

Fama, E.F. \& French, K.R. 2012. Size, value, and momentum in international stock returns. Journal of Financial Economics, 105(3), pp. 457-472.

Hong, H.G., Lim, T., \& Stein, J.C., 2000. Bad news travels slowly: size, analyst coverage, and the profitability of momentum strategies. Journal of Finance, 55(1), pp. 265-295.

Jacobs, H., 2015. What explains the dynamics of 100 anomalies? Journal of Banking \& Finance, 57, pp. 65-85.

Jegadeesh, N. and Titman, S., 1993. Returns to buying winners and selling losers: Implications for stock market efficiency. Journal of Finance, 48(1), pp, 65-91.

Jordan S.J., 2012. Time-varying risk and long-term reversals: a re-examination of the international evidence. Journal of International Business Studies, 43(2), pp. 123-142.

Keppler, M. \& Encinosa, P., 2011. The small-country effect revisited. Journal of Investing, 20(4), pp. 99-103.

Keppler, M. \& Traub, H., 1993. The small-country effect: small markets beat large markets. Journal of Investing, 2(3), pp. 17-24.

Kim, D., 2012. Value premium across countries. Journal of Portfolio Management, 38(4), pp. 75-86.

Liew, J. \& Vassalou, M., 2000. Can book-to-market, size and momentum be risk factors that predict economic growth? Journal of Financial Economics, 57(2), pp. 221-245.

Liu, M., Liu, Q. \& Ma, T., 2011. The 52-week high momentum strategy in international stock markets. Journal of International Money and Finance, 30(1), pp. 180-204.

Macedo, R., 1995. Country-selection style. In Lederman, J. \& Klein, R.A. (eds.) Equity style management: evaluating and selecting investment styles. Burr Ridge: Irwin Professional Publishing. 
Has the Long-Term Reversal Reversed?

Malin, M. \& Bornholt, G., 2013. Long-term return reversal: evidence from international market indices. Journal of International Financial Markets, Institutions and Money, 25, pp. 1-17.

$\mathrm{MSCl}$, 2014a. $\mathrm{MSCl}$ global market accessibility review. Available online: http://www.msci.com/resources/products/indexes/global_equity_index es/gimi/stdindex/MSCl_Global_Market_Accessibiliy_Review_June(20 14).pdf [accessed 14 March 2015].

$\mathrm{MSCl}, 2014 \mathrm{~b} . \mathrm{MSCl}$ global investable market indexes methodology. Available online: http://www.msci.com/eqb/methodology/meth_docs/MSCl_Aug14_GIM IMethod.pdf [accessed 14 March 2015].

Patton A.J. \& Timmermann A., 2010. Monotonicity in asset returns, new tests with applications to the term structure, the CAPM and portfolio sorts. Journal of Financial Economics, 98, pp. 605-625.

Richards, A.J., 1997. Winner-loser reversals in national stock market indices: can they be explained? Journal of Finance, 52(5), pp. 2129-2144.

Smith, D.M. \& Pantilei, V.S., 2015. Do "dogs of the world" bark or bite? Evidence from single-country ETFs. Journal of Investing, 24(1), pp. 7-15.

Spierdijk, L., Bikker, J.A. \& van den Hoek, P., 2012. Mean reversion in international stock markets: an empirical analysis of the 20th century. Journal of International Money and Finance, 31(2), pp. 228-249.

Willenbrock, S. 2011. Diversification return, portfolio rebalancing, and the commodity return puzzle. Financial Analyst Journal, 67(4), pp. $42-49$.

Zaremba, A., 2014. Country selection strategies based on value, size and momentum. Investment Analyst Journal, 44(3), pp. 171-198,

Zaremba, A. \& Konieczka, P., 2015a. Do quantitative country selection strategies really work? Journal of Investment Strategies, forthcoming. Available at SSRN: $\quad$ http://ssrn.com/abstract=2606178 or http://dx.doi.org/10.2139/ssrn.2606178 [accessed 17 February 2016].

Zaremba, A. \& Konieczka, P., 2015b. Are value, size and momentum premiums in CEE emerging markets only illusionary? Finance a úvěr-Czech Journal of Economics and Finance, 65(1), pp. 84-104.

Zhang, X.F., 2006. Information uncertainty and stock returns. Journal of Finance, 61, pp. 105-137. 


\section{Appendix}

\begin{tabular}{|c|c|c|c|c|c|c|c|c|}
\hline ID & Country & Index provider & Start & End & $\mathrm{R}$ & SD & Skew & Kurt \\
\hline 1 & Argentina & $\mathrm{MSCl}$ & 1998-12-31 & 2015-02-28 & 0.59 & 12.16 & -0.69 & 2.57 \\
\hline 2 & Australia & $\mathrm{MSCl}$ & 1995-01-31 & $2015-02-28$ & 0.82 & 6.19 & -0.90 & 2.64 \\
\hline 3 & Austria & $\mathrm{MSCl}$ & 1995-01-31 & 2015-02-28 & 0.21 & 7.87 & -1.50 & 6.91 \\
\hline 4 & Bahrain & $\mathrm{MSCl}$ & 2006-01-31 & $2015-02-28$ & -1.70 & 7.38 & -1.22 & 3.91 \\
\hline 5 & Bangladesh & $\mathrm{MSCl}$ & $2009-11-30$ & 2015-02-28 & 0.15 & 8.59 & -1.17 & 3.74 \\
\hline 6 & Belgium & $\mathrm{MSCl}$ & 1995-01-31 & 2015-02-28 & 0.64 & 6.56 & -2.23 & 11.73 \\
\hline 7 & Brazil & $\mathrm{MSCl}$ & 1998-12-31 & 2015-02-28 & 0.94 & 10.77 & -0.62 & 1.79 \\
\hline 8 & Bulgaria & $\mathrm{MSCl}$ & 2005-05-31 & 2015-02-28 & -1.12 & 11.35 & -1.74 & 8.59 \\
\hline 9 & Canada & $\mathrm{MSCl}$ & 1995-01-31 & $2015-02-28$ & 0.86 & 6.05 & -1.14 & 4.18 \\
\hline 10 & Chile & $\mathrm{MSCl}$ & 1998-12-31 & $2015-02-28$ & 0.78 & 6.43 & -0.73 & 2.77 \\
\hline 11 & China & $\mathrm{MSCl}$ & 1995-01-31 & 2015-02-28 & 0.27 & 9.74 & -0.06 & 2.08 \\
\hline 12 & Colombia & $\mathrm{MSCl}$ & 1998-12-31 & 2015-02-28 & 1.37 & 9.16 & -0.53 & 1.09 \\
\hline 13 & Croatia & $\mathrm{MSCl}$ & 2002-05-31 & 2015-02-28 & 0.40 & 8.01 & -0.29 & 4.14 \\
\hline 14 & Cyprus & Dow Jones & 2004-12-31 & $2015-02-28$ & -3.49 & 22.69 & -3.97 & 30.63 \\
\hline 15 & Czech Rep. & $\mathrm{MSCl}$ & 1998-12-31 & 2015-02-28 & 1.14 & 8.30 & -0.46 & 1.78 \\
\hline 16 & Denmark & $\mathrm{MSCl}$ & 1995-01-31 & $2015-02-28$ & 1.04 & 5.92 & -1.05 & 3.65 \\
\hline 17 & Egypt & $\mathrm{MSCl}$ & 1995-01-31 & $2015-02-28$ & 1.22 & 9.28 & -0.01 & 1.87 \\
\hline 18 & Estonia & $\mathrm{MSCl}$ & 2002-05-31 & 2015-02-28 & 0.86 & 9.49 & -0.66 & 5.83 \\
\hline 19 & Finland & $\mathrm{MSCl}$ & 1995-01-31 & $2015-02-28$ & 0.84 & 9.51 & -0.47 & 1.58 \\
\hline 20 & France & $\mathrm{MSCl}$ & 1995-01-31 & $2015-02-28$ & 0.65 & 6.06 & -0.72 & 1.41 \\
\hline 21 & Germany & $\mathrm{MSCl}$ & 1995-01-31 & 2015-02-28 & 0.66 & 6.88 & -0.89 & 2.33 \\
\hline 22 & Greece & $\mathrm{MSCl}$ & 1995-01-31 & 2015-02-28 & -0.27 & 10.61 & -0.72 & 2.05 \\
\hline 23 & Hong Kong & $\mathrm{MSCl}$ & 1995-01-31 & $2015-02-28$ & 0.71 & 7.20 & -0.41 & 3.21 \\
\hline 24 & Hungary & $\mathrm{MSCl}$ & 1998-12-31 & $2015-02-28$ & 0.27 & 10.57 & -1.14 & 4.20 \\
\hline 25 & Iceland & Dow Jones & 2007-01-31 & 2015-02-28 & -2.30 & 23.77 & -7.90 & 71.25 \\
\hline 26 & India & $\mathrm{MSCl}$ & 1995-01-31 & $2015-02-28$ & 0.71 & 8.76 & -0.27 & 0.74 \\
\hline 27 & Indonesia & $\mathrm{MSCl}$ & 1998-12-31 & $2015-02-28$ & 1.29 & 10.82 & -0.47 & 2.62 \\
\hline 28 & Ireland & $\mathrm{MSCl}$ & 1995-01-31 & 2015-02-28 & 0.21 & 6.72 & -1.24 & 3.18 \\
\hline 29 & Israel & $\mathrm{MSCl}$ & 1998-12-31 & $2015-02-28$ & 0.64 & 6.82 & -0.52 & 1.48 \\
\hline 30 & Italy & $\mathrm{MSCl}$ & 1995-01-31 & 2015-02-28 & 0.38 & 7.06 & -0.41 & 0.62 \\
\hline 31 & Japan & $\mathrm{MSCl}$ & 1995-01-31 & 2015-02-28 & 0.07 & 5.26 & -0.08 & 0.01 \\
\hline 32 & Jordan & $\mathrm{MSCl}$ & 1998-12-31 & 2015-02-28 & 0.32 & 5.71 & -0.44 & 3.41 \\
\hline 33 & Kazakhstan & $\mathrm{MSCl}$ & $2005-11-30$ & 2015-02-28 & 0.67 & 12.68 & 1.68 & 9.79 \\
\hline 34 & Kenya & $\mathrm{MSCl}$ & 2002-05-31 & 2015-02-28 & 2.06 & 8.26 & -0.83 & 3.53 \\
\hline 35 & Kuwait & $\mathrm{MSCl}$ & 2006-01-31 & $2015-02-28$ & -0.15 & 6.94 & -0.45 & 1.76 \\
\hline 36 & Lebanon & $\mathrm{MSCl}$ & 2002-05-31 & 2015-02-28 & 0.73 & 8.44 & 0.64 & 4.08 \\
\hline 37 & Lithuania & $\mathrm{MSCl}$ & $2008-05-30$ & 2015-02-28 & 0.40 & 8.42 & 0.24 & 8.95 \\
\hline 38 & Malaysia & $\mathrm{MSCl}$ & 1998-12-31 & 2015-02-28 & 1.04 & 6.13 & 0.46 & 3.65 \\
\hline 39 & Mexico & $\mathrm{MSCl}$ & 1995-01-31 & $2015-02-28$ & 0.96 & 8.20 & -1.26 & 4.32 \\
\hline 40 & Morocco & $\mathrm{MSCl}$ & 1998-12-31 & 2015-02-28 & 0.37 & 5.55 & 0.05 & 1.18 \\
\hline 41 & Netherlands & $\mathrm{MSCl}$ & 1995-01-31 & 2015-02-28 & 0.66 & 6.10 & -1.14 & 2.99 \\
\hline 42 & New Zealand & $\mathrm{MSCl}$ & 1995-01-31 & 2015-02-28 & 0.56 & 6.40 & -0.83 & 1.67 \\
\hline 43 & Nigeria & $\mathrm{MSCl}$ & 2009-09-30 & 2015-02-28 & 0.39 & 6.76 & -0.48 & 0.21 \\
\hline 44 & Norway & $\mathrm{MSCl}$ & 1995-01-31 & $2015-02-28$ & 0.66 & 8.01 & -1.31 & 4.99 \\
\hline
\end{tabular}


Has the Long-Term Reversal Reversed?

Research sample -Table A1 continued

Table A1

\begin{tabular}{|c|c|c|c|c|c|c|c|c|}
\hline ID & Country & \begin{tabular}{|l|} 
Index \\
provider
\end{tabular} & Start & End & $\mathrm{R}$ & SD & Skew & Kurt \\
\hline 45 & Oman & $\mathrm{MSCl}$ & $2005-05-31$ & 2015-02-28 & 0.03 & 6.15 & -1.91 & 8.92 \\
\hline 46 & Pakistan & $\mathrm{MSCl}$ & 2002-05-31 & $2015-02-28$ & 1.45 & 9.55 & -2.80 & 19.39 \\
\hline 47 & Peru & MSCI & 1998-12-31 & 2015-02-28 & 1.36 & 8.50 & -0.88 & 3.78 \\
\hline 48 & Philippines & $\mathrm{MSCl}$ & 1998-12-31 & $2015-02-28$ & 0.66 & 7.49 & -0.35 & 0.82 \\
\hline 49 & Poland & $\mathrm{MSCl}$ & 1998-12-31 & $2015-02-28$ & 0.56 & 9.98 & -0.55 & 1.30 \\
\hline 50 & Portugal & $\mathrm{MSCl}$ & 1995-01-31 & $2015-02-28$ & 0.29 & 6.68 & -0.78 & 1.74 \\
\hline 51 & Qatar & $\mathrm{MSCl}$ & 2006-01-31 & $2015-02-28$ & 0.45 & 8.42 & -0.88 & 2.64 \\
\hline 52 & Romania & $\mathrm{MSCl}$ & $2005-11-30$ & 2015-02-28 & 0.02 & 12.92 & -1.73 & 7.21 \\
\hline 53 & Russia & $\mathrm{MSCl}$ & 1998-12-31 & $2015-02-28$ & 1.23 & 11.68 & -0.13 & 2.08 \\
\hline 54 & Serbia & $\mathrm{MSCl}$ & $2008-05-30$ & $2015-02-28$ & -1.97 & 15.57 & -1.41 & 6.31 \\
\hline 55 & Saudi Arabia & $\mathrm{MSCl}$ & 2006-01-31 & 2008-05-31 & -2.27 & 12.50 & -0.13 & -0.96 \\
\hline 56 & Singapore & $\mathrm{MSCl}$ & 1995-01-31 & $2015-02-28$ & 0.35 & 7.44 & -0.66 & 3.04 \\
\hline 57 & Slovenia & $\mathrm{MSCl}$ & 2002-05-31 & 2015-02-28 & 0.39 & 6.87 & -0.41 & 2.16 \\
\hline 58 & South Africa & $\mathrm{MSCl}$ & 1998-12-31 & 2015-02-28 & 0.88 & 7.49 & -0.63 & 0.85 \\
\hline 59 & South Korea & $\mathrm{MSCl}$ & 1998-12-31 & 2015-02-28 & 0.86 & 9.06 & -0.07 & 0.65 \\
\hline 60 & Spain & $\mathrm{MSCl}$ & 1995-01-31 & $2015-02-28$ & 0.78 & 7.13 & -0.64 & 1.80 \\
\hline 61 & Sri Lanka & $\mathrm{MSCl}$ & 2002-05-31 & $2015-02-28$ & 1.03 & 9.15 & 1.01 & 5.16 \\
\hline 62 & Sweden & $\mathrm{MSCl}$ & 1995-01-31 & 2015-02-28 & 0.88 & 7.49 & -0.59 & 2.01 \\
\hline 63 & Switzerland & $\mathrm{MSCl}$ & 1995-01-31 & $2015-02-28$ & 0.78 & 4.88 & -0.66 & 0.97 \\
\hline 64 & Taiwan & $\mathrm{MSCl}$ & 1998-12-31 & 2015-02-28 & 0.32 & 7.65 & -0.06 & 0.74 \\
\hline 65 & Thailand & $\mathrm{MSCl}$ & 1998-12-31 & 2015-02-28 & 0.87 & 9.35 & -0.40 & 2.80 \\
\hline 66 & Trin. & $\mathrm{MSCl}$ & $2008-11-28$ & $2015-02-28$ & 0.52 & 2.86 & -0.03 & 3.08 \\
\hline 67 & Tunisia & $\mathrm{MSCl}$ & 2004-05-31 & 2015-02-28 & 0.55 & 5.08 & 0.20 & 3.48 \\
\hline 68 & Turkey & $\mathrm{MSCl}$ & 1998-12-31 & $2015-02-28$ & 0.71 & 14.30 & -0.26 & 1.86 \\
\hline 69 & Ukraine & $\mathrm{MSCl}$ & 2006-05-31 & 2015-02-28 & -2.74 & 13.42 & -0.71 & 1.36 \\
\hline 70 & UEA & $\mathrm{MSCl}$ & 2005-05-31 & $2015-02-28$ & -0.30 & 10.91 & -0.35 & 1.49 \\
\hline 71 & UK & $\mathrm{MSCl}$ & 1995-01-31 & 2015-02-28 & 0.55 & 4.64 & -0.66 & 2.09 \\
\hline 72 & USA & $\mathrm{MSCl}$ & 1995-01-31 & $2015-02-28$ & 0.76 & 4.43 & -0.85 & 1.58 \\
\hline 73 & Venezuela & $\mathrm{MSCl}$ & 1998-12-31 & 2007-12-31 & 0.95 & 13.07 & 0.30 & 4.05 \\
\hline 74 & Vietnam & $\mathrm{MSCl}$ & 2006-11-30 & 2015-02-28 & -0.22 & 11.40 & 0.44 & 2.10 \\
\hline
\end{tabular}

Note. In the table, ID is a running number; Start and End refer to the first and last observations in the sample period; $R$ to mean monthly log-return, SD - standard deviation of log-returns, Skew skewness, Kurt - kurtosis. $R$ and SD are expressed in percentage terms. 